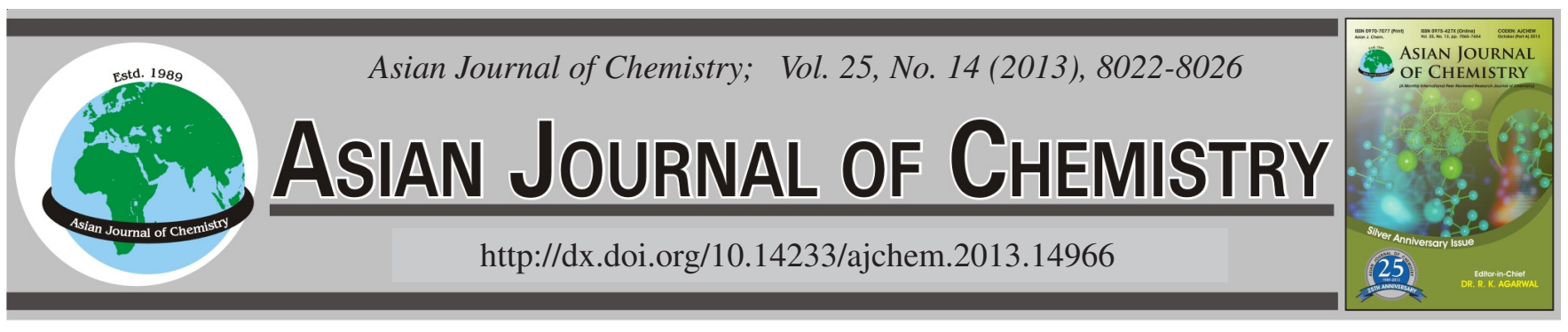

\title{
Effect of Graphene Modified Cathode on Paracetamol Removal in Microbial Fuel Cell
}

\author{
Jing Chen, Shengke Yang ${ }^{*}$, Wenke Wang, Bin Li, Lunchuan Gao and Yuanyuan Liu
}

Key Laboratory of Subsurface Hydrology and Ecology in Arid Areas, Ministry of Education, School of Environmental Science and Engineering, Chang'an University, Xi'an 710054, P.R. China

*Corresponding author: Fax: +86 29 85585485; Tel: +86 29 82339982; E-mail: ysk110@126.com; cj120325@gmail.com

(Received: 12 December 2012;

Accepted: 29 July 2013)

AJC-13864

Paracetamol was used as the anode substrate to build dual chamber microbial fuel cells with graphene modified cathode to improve the
performance of reactors. Results verified, graphene modified reactor could improve paracetamol removal rate by $18 \%$ compared to
unmodified reactor and the daily average voltage curve of modified reactor was higher as well. Daily average voltage curves affected by
the response of microbial to paracetamol,results indicated that the voltage curve was more stable and higher under lower paracetamol
concentration at the beginning. However, the long term performance of microbial fuel cell was better under higher paracetamol concen-
tration, how long the running time would continue didn't accord with the increasing of paracetamol concentration because of the toxicity
of paracetamol to microorganisms. Simultaneously, removal rate of paracetamol was tested under different salt bridge diameters. The
highest removal rate was obtained with cross-section(S) of $28.26 \mathrm{~mm}^{2}(\Phi 6)$. These results show that this processing mode using graphene
modified microbial fuel cells to degrade paracetamol was feasible and in favour of promoting the removal rate of paracetamol.
Key Words: Graphene, Microbial fuel cell, Paracetamol, Catalyst.

\section{INTRODUCTION}

Microbial fuel cell (MFC) is a bioreactor, which can convert chemical energy to electricity through the catalytic reaction of anaerobic microorganisms. Many organic matters have been reported be employed as microbial fuel cell anode substrate, including glucose ${ }^{1}$, acetic $\operatorname{acid}^{2}$, ethanol ${ }^{3}$, quinoline morpholine ${ }^{4}$ and phenol $^{5}$, etc. The performance of microbial fuel cell varies with different experimental conditions.

Microbial fuel cell performance varied depending on factors such as the type of the carbon source, the battery configuration, the type of the electrode, operating temperature, the type of cathode catalyst, the nature of the anode biocatalyst ${ }^{6}$, wherein the type of cathode catalyst is one of the key factors that affects the performance of the microbial fuel cell. Platinum is the best known solid catalyst. Uría et al. ${ }^{7}$ compared the maximum output power of platinum foil, platinum black, platinum-coated silicon wafers and stainless steel cathode and drew a conclusion that the maximum output power reduced in accordance with the order of platinum foil, platinum black, platinum-coated silicon wafers and stainless steel and their maximum output power curves were stable except platinumcoated silicon wafers having a rising maximum output power curve. However, platinum-based electrodes are not useful for practical applications due to high cost of platinum, tendency to poisoning by the formation of a platinum oxide layer at the surface and sensitivity to biological and chemical fouling. For this reason, different and low cost alternative cathode catalysts have been studied such as metal macrocyclic compound catalysts, metal aliphatic polyamine catalysts, metal polypyrrole catalysts $^{8}$, these production processes are complex and their performances are different.

Graphene as a two-dimensional structure new carbon material has a unique structure and superior performance. It has a large specific surface area, the theoretical value up to $2630 \mathrm{~m}^{2} / \mathrm{g}^{9}$, the electron mobility up to $15000 \mathrm{~cm}^{2} \mathrm{v}^{-1} \mathrm{~s}^{-1}$, this is known as the fastest one until now ${ }^{10}$. Graphene is a low-cost material with good machinability, electrocatalysis to the test substance and can achieve a good reproducibility as well. As reported, graphene modified electrodes have been employed in determining the electrochemical behavour of enzymes and concentration of small molecules ${ }^{11}$, as well as the concentration of trace mercury ${ }^{12}$ and trace copper ions etc. ${ }^{13}$. These results showed that graphene modified electrodes can effectively improve the sensitivity of these experiment methods, but there still has no study combine graphene modified electrodes with microbial fuel cell.

Paracetamol (acetaminophen, N-acetyl-4-aminophenol) is widely used as an antipyretic and analgesic drug in therapy for fever, coughing, colds and pain. Many countries and regions 
have reported the detection of paracetamol up to $0.211^{14}, 1.1^{15}$, $6.2 \mu \mathrm{g} / \mathrm{L}^{16}$ and may be higher now, it can be accumulated ${ }^{17}$ and its half-life was over 20 years ${ }^{18}$. With a continuous detection of paracetamol in a variety of water bodies, the removal of paracetamol has drawn researcher's attention. Studies have shown that paracetamol in distilled water can be removed completely with 20 min ozone oxidation process and the mineralization rate is $30 \%$ after $2 \mathrm{~h}^{19}$. But ozone oxidation process will consume large amounts of power, which is not necessarily rational in economy and the mineralization rate is low. Chlorination process can reduce the concentration of paracetamol in waste water below instrument detection limit ${ }^{20}$. However, this method will produce two annular chlorinated products and two toxic compounds, which have relation to human overdose lethal effect ${ }^{21}$. While using ultrafiltration-reverse osmosisactivated carbon adsorption combined wastewater treatment technology can almost completely remove paracetamol in sewage ${ }^{18}$, but we will face with many problems simultaneously, such as, the complex process, high quality requirement of inflow, expensive membrane module in membrane bioreactor technology and membrane module cleaning and restoration.

Therefore, graphene was employed as a cathode catalyst to modify copper, simultaneously, paracetamol was used as the anode substrate to build dual-chamber microbial fuel cell. There still has no study reported at home and abroad about whether paracetamol can be degrade under appropriate microbial fuel cell conditions and whether graphene can improve microbial fuel cell performance effectively. We have done a preliminary study on this issue, which will provide new ideas and technologies to low-energy treatment with paracetamol wastewater.

\section{EXPERIMENTAL}

Reactor configuration: In this study, a two-chamber fuel cell was used. The cathode chamber was filled with $250 \mathrm{~mL}$ of $50 \mathrm{mM}$ ferricyanide $\left(\mathrm{K}_{3}\left[\mathrm{Fe}(\mathrm{CN})_{6}\right]\right.$ in a $0.2 \mathrm{M} \mathrm{pH} 7$ phosphate buffer), copper sheets with the size $6 \mathrm{~cm} \times 4 \mathrm{~cm} \times 0.15$ $\mathrm{cm}$ and purity of more than $99.9 \%$ was used as basic material for cathode, unmodified copper cathode was used in control reactor and modified copper cathodes were used in test reactors. In the anode chamber, stainless steel wire mesh (80 meshes, $6 \mathrm{~cm} \times 4 \mathrm{~cm}$ ) was employed as anode material because of its large superficial area. All the microbial fuel cell anode chambers were inoculated from student cafeteria sewage, stainless steel wire meshes were placed in this sewage with nutrient solution and $50 \mathrm{mg} / \mathrm{L}$ paracetamol under anaerobic conditions for one week, facilitating the domestication and inoculation of microorganisms. The anode culture medium contained (per liter): $\mathrm{Na}_{2} \mathrm{HPO}_{4}$ (4.089 g), $\mathrm{NaH}_{2} \mathrm{PO}_{4}(2.544 \mathrm{~g}$ ), $\mathrm{KCl}(0.13 \mathrm{~g}), \mathrm{MgCl} \cdot 6 \mathrm{H}_{2} \mathrm{O}(0.1 \mathrm{~g}), \mathrm{CaCl}_{2}(0.1 \mathrm{~g}), \mathrm{NaCl}(2.9 \mathrm{~g})$, $400 \mathrm{mg} / \mathrm{L}$ paracetamol (except concentration control experiments) and other essential trace elements. This anode culture medium was employed in the experimental process and the volume is $250 \mathrm{~mL}$.

In those two-chamber fuel cells, anode and cathode electrode were link together with copper wire and $1 \mathrm{k} \Omega$ external resistance to constitute a closed loop, this resistor value was chosen following the most common studies up to that date, enabling comparison with the results of our test. Cathode and anode chamber were closed with lids provided with sampling points and anode chamber was sparged with nitrogen at the beginning of experiments to remove oxygen. All experiments were operated under room temperature(average temperature $15^{\circ} \mathrm{C}$ ) and anaerobic condition.

In our case, we employed graphene microchip to modify copper cathode with carboxymethyl cellulose sodium (CMC) as dispersant. Firstly, $2 \mathrm{~g} \mathrm{CMC}$ and $1 \mathrm{~g}$ graphene microchip (GPNs, Xiamen Knano Graphene Technology Co., Ltd., particle size $0.5-20 \mu \mathrm{m}$, thickness $5-25 \mathrm{~nm}$, specific surface area $40-60 \mathrm{~m}^{2} / \mathrm{g}$, density $2.25 \mathrm{~g} / \mathrm{cm}^{3}$ ) was weighted and diluted with distilled water, then dissolved the above solutionfully by ultrasonic dispersion for $20 \mathrm{~min}$, making the concentration of $\mathrm{CMC}$ and graphene were 10 and $5 \mathrm{mg} / \mathrm{mL}$, respectively. And finally, placed the pretreated copper sheets ${ }^{22}$ in and immersed $5 \mathrm{~min}$, then dried them in the air, that's the graphene modified cathode we required. This method using graphene to modify microbial fuel cell is simple and easy to prepare modified electrodes.

Impact of microbial fuel cells with modified and unmodified copper cathode on output voltage and paracetamol removal: To study the effect of the modified copper cathode on paracetamol removal and output voltage of microbial fuel cells,graphene microchip in our study was applied to modify copper cathode with CMC as dispersant, meanwhile using unmodified copper as the cathode incontrol experiment.The output voltage and paracetamol removal were detected when the concentration of paracetamol was $400 \mathrm{mg} / \mathrm{L}$ in the anode chamberand the diameter of the salt bridge is $6 \mathrm{~mm}(\mathrm{~S}=28.26$ $\mathrm{mm}^{2}$ ). Meanwhile, these cells were executed under identical conditions.

Impact of the paracetamol concentration on output voltage: Paracetamol has a mixed human medical efficacy and its content has a strict control, thus we wonder if the activity of microbes and even the operation of microbial fuel cells would be impacted as well. Thus, we study the effect on output voltage when paracetamol concentrations are 400, 800 and $1600 \mathrm{mg} / \mathrm{L}$, while maintaining a constant diameter of the salt bridge of $6 \mathrm{~mm}$ and identical modified cells. These cells were executed under identical conditions.

Impact of the diameter of salt bridge on paracetamol removal: Salt bridge is a low cost conductive medium and can be fabricated easily. To analyze the effect of different diameters of the salt bridge on paracetamol removal of microbial fuel cells, we compared four different diameters of the salt bridge $\left(\mathrm{S}=7.065 \mathrm{~mm}^{2}(\Phi 3), \mathrm{S}=14.13 \mathrm{~mm}^{2}(2 \times \Phi 3), \mathrm{S}=\right.$ $28.26 \mathrm{~mm}^{2}(\Phi 6)$ and $\mathrm{S}=50.24 \mathrm{~mm}^{2}(\Phi 8)$ ), while maintaining a constant concentration of paracetamol of $400 \mathrm{mg} / \mathrm{L}$ and identical modified cells. Meanwhile, these cells were executed under identical conditions.

Measurements and analysis: The voltage values were determined by the self-madedata collection device (voltage range from $0-2.5 \mathrm{~V}$, sampling precision $10^{-5} \mathrm{~V}$ ), collected once every $5 \mathrm{~min}$ and recorded on computer automatically, the average voltage were calculated by voltage value collected of each day. Paracetamol concentration was determined by UPLC (Waters ACQUITY UPLC), methanol:water (50:50 v/v) as a mobile phase, detected wavelength of $249 \mathrm{~nm}$ and a flow rate of $0.2 \mathrm{~mL} / \mathrm{min}$, the chromatographic column is column $\mathrm{BEH}$ 
Shield RP-18 (1.7 $\mu \mathrm{m}, 2.1 \times 150$ column $)$, column temperature was $20 \pm 0.1^{\circ} \mathrm{C}$, retention time was $2.190 \mathrm{~min}, 5 \mu \mathrm{L}$ injection volume and microfilter was used with $0.45 \mu \mathrm{m}$. Paracetamol removal rate was calculated as $\eta=\left(\mathrm{C}_{0}-\mathrm{C}_{\mathrm{i}}\right) / \mathrm{C}_{\mathrm{o}} \times 100 \%$, where $\eta$ represents the removal rate of the paracetamol, $\mathrm{C}_{\mathrm{o}}$ represents the initial concentration of paracetamol, $\mathrm{C}_{\mathrm{i}}$ represents residual concentration of paracetamol in reactor.

\section{RESULTS AND DISCUSSION}

Impact of microbial fuel cells with graphene modified on output voltage and removal rate

Output voltage of microbial fuel cells: The voltage of graphene modified microbial fuel cell and unmodified microbial fuel cell were studied when the initial concentration of paracetamol in anode were $400 \mathrm{mg} / \mathrm{L}$ (Fig. 1). As can be seen from the figure, the daily average voltage of the two reactors were significantly different, average voltage of the graphene modified microbial fuel cell is higher. Throughout the experimental stage, the two of microbial fuel cells have similar performance period, this demonstrated that graphene as a catalyst in cathode was effective to electricity production.

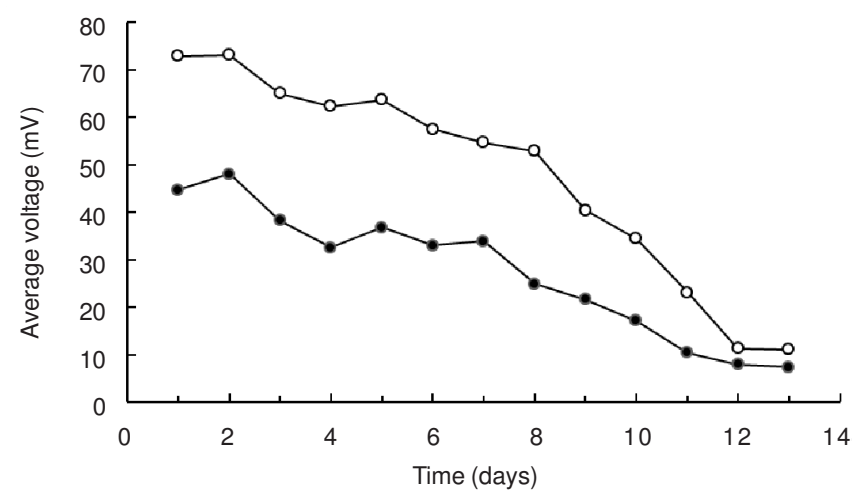

Fig. 1. Effect of microbial fuel cell with graphene modified cathode on average voltage $(\mathrm{O}$ : Microbial fuel cell with graphene modified cathode, Microbial fuel cell with unmodified cathode)

Removal rate of paracetamol in microbial fuel cells: In the study we compared the paracetamol removal of modified microbial fuel cell with unmodified microbial fuel cell while the substrate initial concentration of paracetamol is $400 \mathrm{mg} / \mathrm{L}$. The result was shown in Fig. 2, the figure indicated that graphene modified cathode microbial fuel cell showed a stable and higher biodegradability, the removal rate of paracetamol reached to $68 \%$ with a degradation rate of $1.23 \mathrm{mg} /(\mathrm{L} \mathrm{h})$. While the removal rate of paracetamol was only $50 \%$ in unmodified microbial fuel cell with the degradation rate of $0.93 \mathrm{mg} /(\mathrm{L} \mathrm{h})$. Hence, it is concluded that the graphene played a significant help to improve the microbial fuel cell performance, it is conducive to the removal of paracetamol.

UPLC analysis of paracetamol: We carried through ultra-high performance liquid chromatogram (UPLC) analysis of paracetamol in anolyte for $1^{\text {st }}, 5^{\text {th }}, 10^{\text {th }}$ day, respectively (Fig. 3), it can be seen that microbial fuel cell reactors have obvious accumulation of byproduct. Khamis et al ${ }^{18}$ mentioned that paracetamol was found to degrade into acetic acid and $p$ aminophenol via a base or acid hydrolysis of the amide bond,

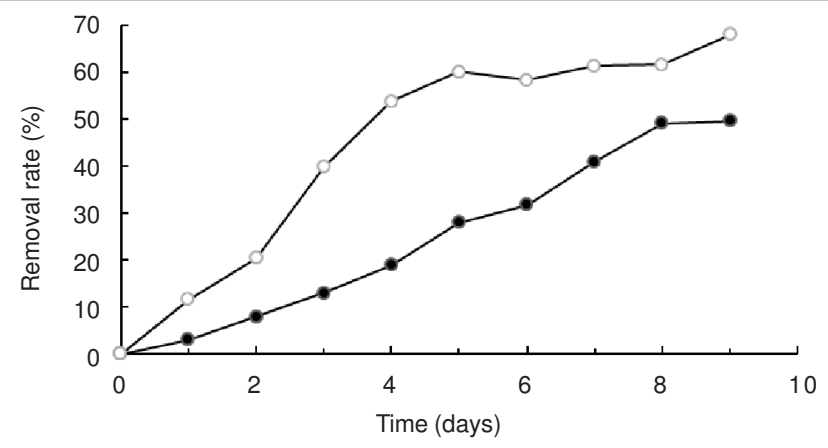

Fig. 2. Effect of microbial fuel cell with graphene modified cathode on the removal of paracetamol $(\bigcirc$ : Microbial fuel cell with graphene modified cathode, : Microbial fuel cell with unmodified cathode)

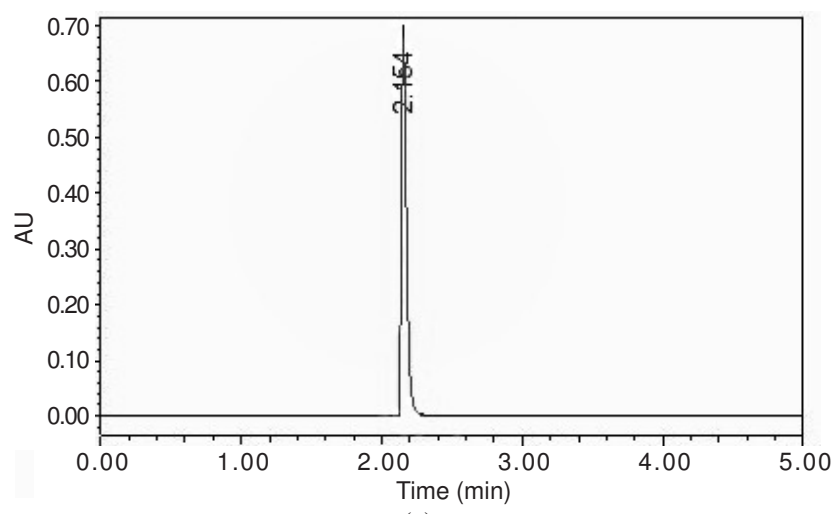

(a)

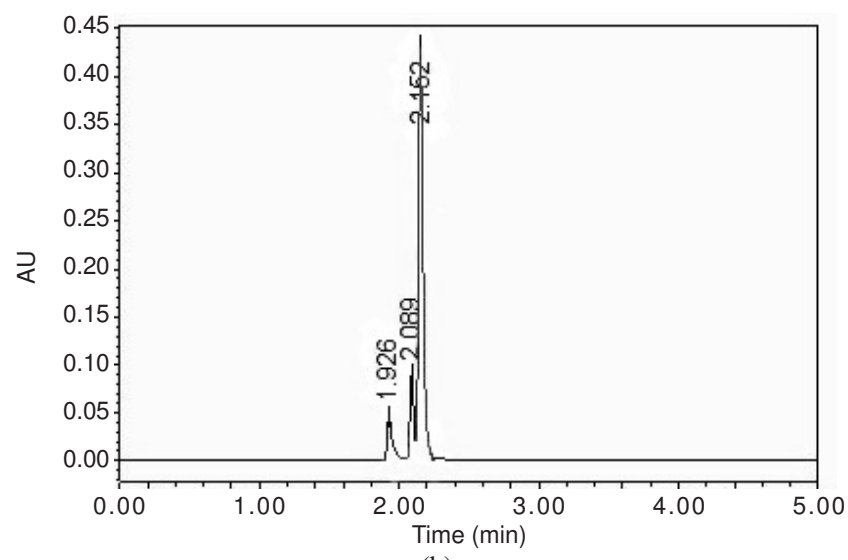

(b)

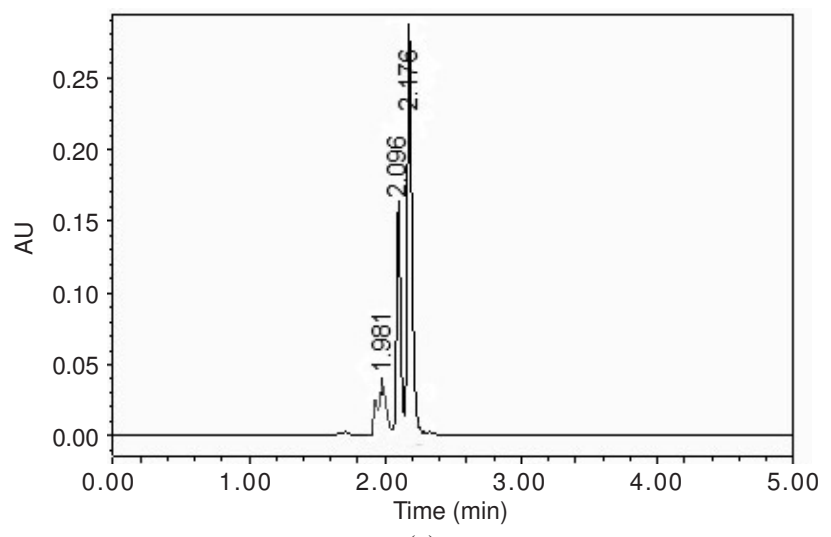

(c)

Fig. 3. UPLC chromatography of paracetamol in the anode chamber solution [the figure sequentially shows paracetamol concentration of the $1^{\text {st }}$ day (a), $5^{\text {th }}$ day (b) and $10^{\text {th }}$ day (c)] 
but it hasn't been determined whether they were acetic acid and $p$-aminophenol or not in our reactors due to the available experimental conditions, this needs our further study.

Impact of the paracetamol concentration on output voltage : In this study, three graphene modified microbial fuel cells were employed with the concentration of paracetamol 400,800 and $1600 \mathrm{mg} / \mathrm{L}$ successively to investigate the effect on electricity production, the daily average voltage curves were shown in Fig. 4. Fig. 4 showed that the highest and stable daily voltage value was obtained when paracetamol concentration was $400 \mathrm{mg} / \mathrm{L}$, while daily voltage value with paracetamol concentration of 800 and $1600 \mathrm{mg} / \mathrm{L}$ have fluctuated quite a bit. The higher of concentration, the greater of voltage value drop. The voltage value have decreased to 10 $\mathrm{mV}$ with paracetamol concentration of 400 and $1600 \mathrm{mg} / \mathrm{L}$ as the experiment went on, while the microbial fuel cell has a final voltage value of $20 \mathrm{mV}$ with concentration of $800 \mathrm{mg} / \mathrm{L}$, which was twice than the former. It can be speculated that the decline of voltage in early days was not due to the deficiencies of the substrates, but because the concentration was too large on the contrary. Microorganisms living in a high concentration of paracetamol solution for a long time will bring adverse impact to electricity production. However, the system can run a longer time with suitable substrate concentration correspondingly.

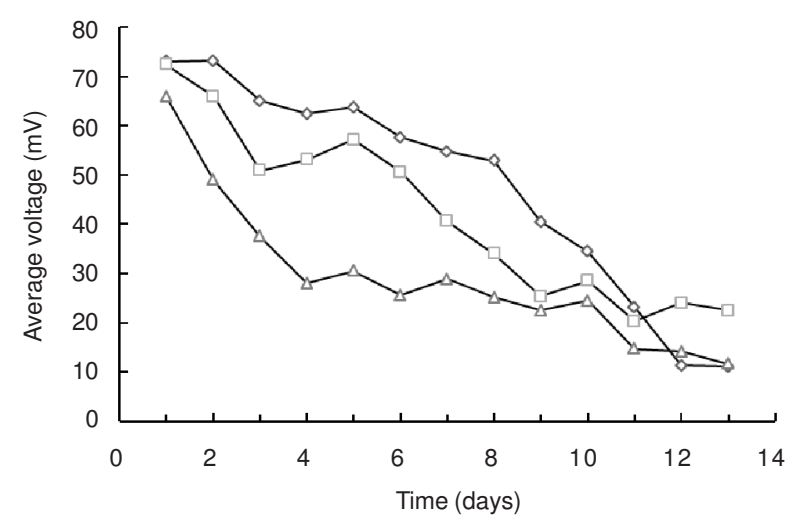

Fig. 4. Average voltage curve on different paracetamol concentrations $(\diamond)$ $400 \mathrm{mg} / \mathrm{L}, \square: 800 \mathrm{mg} / \mathrm{L}, \Delta: 1600 \mathrm{mg} / \mathrm{L}$ )

Kuhn et $a l . .^{23}$ confirmed that the concentration of paracetamol can cause $48 \mathrm{~h} \mathrm{EC}_{50}(50 \%$ of individual effective dose) of daphnia is $9200 \mu \mathrm{g} / \mathrm{L}$. The concentration that can cause $24 \mathrm{~h} \mathrm{LC}_{50}$ (median lethal dose) of fairy shrimp is 29600 $\mu \mathrm{g} / \mathrm{L}$. Henschel et al. ${ }^{24}$ have reported that the concentration of paracetamol can cause $\mathrm{EC}_{50}$ at $48 \mathrm{~h}$ of ciliates is $112 \mathrm{mg} / \mathrm{L}$, of luminous bacteria is $650 \mathrm{mg} / \mathrm{L}$ and of daphnia is $50 \mathrm{mg} / \mathrm{L}$ while its $\mathrm{EC}_{50}$ values in $24 \mathrm{~h}$ is $293 \mathrm{mg} / \mathrm{L}$. These conclusions as well confirmed that paracetamol is not only produce side effects to human liver but also to microorganisms and different species have large differences responding to paracetamol, while the impact is the same to one organism of longer time with lower paracetamol concentration contrast to short time with higher paracetamol concentration.

It can be inferred that the reasons why this experiment hasn't reach a high voltage output possible are because: the large internal resistance of salt bridge, stainless steel mesh can't have an ideal electricity production even through it meets many of the requirements of the anode material ${ }^{25}$, high paracetamol concentration will produced toxic effects to microorganisms. In present study microorganisms were inoculated from the canteen sewage, which has little chances to contact with those compounds as paracetamol, so if we want to gain a favourable electricity production, it's bound to increase the acclimation time of microbial to increase their adaptation of paracetamol.

Impact of the diameter of salt bridge on removal rate: The diameter of the salt bridge was described with crosssectional area (S), we employed four different diameters of salt bridge $\left(\mathrm{S}=7.065 \mathrm{~mm}^{2}(\Phi 3), \mathrm{S}=14.13 \mathrm{~mm}^{2}(2 \times \Phi 3), \mathrm{S}=\right.$ $28.26 \mathrm{~mm}^{2}(\Phi 6)$ and $\mathrm{S}=50.24 \mathrm{~mm}^{2}(\Phi 8)$ ) to examine the removal rate of paracetamol when the paracetamol concentration is $400 \mathrm{mg} / \mathrm{L}$. As can be seen from the following diagram (Fig. 5), paracetamol removal rate was up to $68 \%$ when $\mathrm{S}=28.26 \mathrm{~mm}^{2}$, while paracetamol removal rate is the lowest with $\mathrm{S}=50.24 \mathrm{~mm}^{2}$ and the removal rate were relatively similar in the remaining two reactors.

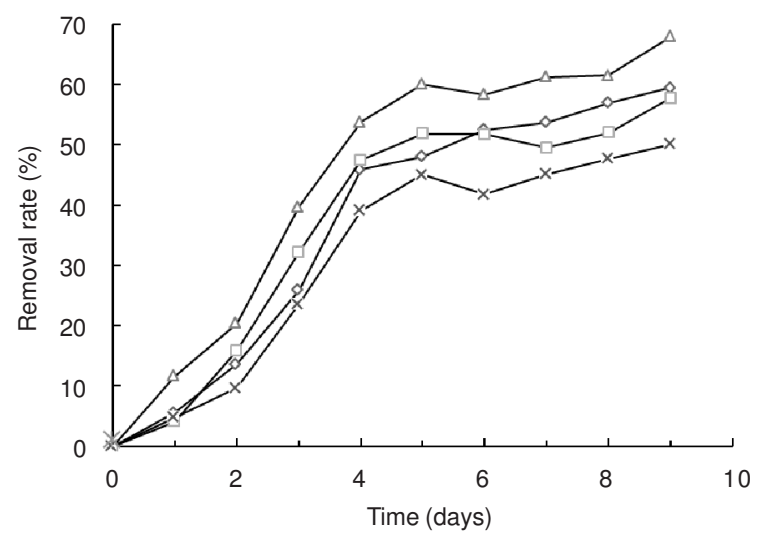

Fig. 5. Removal rate of paracetamol under the conditions of different diameters $\left(\diamond: \mathrm{S}=7.065 \mathrm{~mm}^{2}, \square: \mathrm{S}=14.13 \mathrm{~mm}^{2}, \Delta: \mathrm{S}=28.26 \mathrm{~mm}^{2}\right.$, $\mathrm{x}: \mathrm{S}=50.24 \mathrm{~mm}^{2}$ )

Although the difference is not so obvious, we can see that the diameter of the salt bridge increases does not necessarily improved microbial fuel cell performance and the most suitable diameter can be found under certain experimental conditions. Because the increasing of diameter, on the one hand, is conducive to the transfer of protons thereby adjust $\mathrm{pH}$ values between cathode and anode, on the other hand, other anions and cations would be migrated at the same time which can narrow the potential difference between anode and cathode reducing the difference of potential that would hinder the removal of paracetamol in return. Huang et al. ${ }^{26}$ also proved that there existed a limit of output voltage caused by the increase of the diameter of salt bridge and the relation between output voltage and removal rate need our further discussion.

\section{Conclusion}

Graphene was applied successfully into microbial fuel cell reactors as a cathode catalyst in this article, this modified cathode cell was not only capable of degrading paracetamol but also enhanced its removal rate. In contrast to the unmodified cathode microbial fuel cell, paracetamol removal rate was 
$18 \%$ higher in modified cell with the degradation rate of 1.23 $\mathrm{mg} /(\mathrm{L} \mathrm{h})$. The removal rate of paracetamol differed with the salt bridge diameter varied and there existed a limitation of the removal rate under certain experimental conditions, thus we can find a suitable diameter with highest paracetamol removal rate. The change of voltage value didn't accord with the change of paracetamol concentration when the experiment carried through under room temperature, the average daily voltage curve declined more obvious accompanying with big fluctuation as the concentration of paracetamol increasing, but the long term performance of microbial fuel cells can continue relatively longer under suitable substrate concentration. This method using graphene to modify microbial fuel cell is effective, rational in economy and easy to prepare modified electrodes.

\section{ACKNOWLEDGEMENTS}

Funding for this study was provided by the National Natural Science Foundation of China (No. 41072185) and the Central University Special Fund.

\section{REFERENCES}

1. S.K. Chaudhuri and D.R. Lovley, Nat. Biotechnol., 21, 1229 (2003).

2. M.Z. Fan, P. Liang, X.X. Cao and X. Huang, Environ. Sci., 29, 263 (2008).

3. J. R. Kim, S.H. Jung, J.M. Regan and B.E. Logan, Bioresour. Technol., 98, 2568 (2007)

4. C.P. Zhang, Z.Q. Wang, G.L. Liu, H.P. Luo and R.D. Zhang, Acta Sci. Circumst., 29, 740 (2009).

5. J.Q. Wang, X.L. Xia and W.W. Ding, Acta Sci. Circumst., 30, 735 (2010)
6. P. Kaewkannetra, W. Chiwes and T.Y. Chiu, Fuel, 90, 2746 (2011).

7. N. Uría, D. Sánchez, R. Mas, O. Sánchez, F.X. Muñoz and J. Mas, Sens. Actuators B, 170, 88 (2012).

8. Z.F. Ma, H.J. Zhang, X.X. Yuan and Q.Z. Jiang, Chem. Ind. Eng. Prog., 30, 150 (2011).

9. Q.H. Yang and Z.Y. Tang, Chin. J. Power Sources, 33, 241 (2009).

10. J.H. Chen, C. Jang, S. Xiao, M. Ishigami and M.S. Fuhrer, Nat. Nanotechnol., 3, 206 (2008).

11. Z.H. Chen, Y.Q. Ge, Q.H. Jin, J.S. Liu and J.L. Zhao, Chem. Sensors, 30, 9 (2010).

12. C.X. Xu, X.Q. Xiong, Y.Y. Wu and W.J. Ma, Chin. J. Appl. Chem., 28, 969 (2011)

13. Y.H. Fang, H.T. Lian and G.H. Chen, J. Huaqiao Univ. (Nat. Sci.), 32, 529 (2011).

14. M. Rabiet, A. Togola, F. Brissaud, J. Seidel, H. Budzinski and F. Elbazpoulichet, Environ. Sci. Technol., 40, 5282 (2006).

15. D.W. Kolpin, E.T. Furlong, M.T. Meyer, E.M. Thurman, S.D. Zaugg, L.B. Barber and H.T. Buxton, Environ. Sci. Technol., 36, 1202 (2002).

16. M. Petrovic, M. Gros and D. Barcelo, J. Chromatogr. A, 1124, 68 (2006).

17. C.A. Kinney, E.T. Furlong, S.L. Werner and J.D. Cahill, Environ. Toxicol. Chem., 25, 317 (2006)

18. M. Khamis, R. Karaman, F. Ayyash, A. Qtait, O. Deeb and A. Manssra, J. Environ. Sci. Eng., 5, 121 (2011).

19. R. Andreozzi, V. Caprio, R. Marotta and D. Vogna, Water Res., 37, 993 (2003).

20. G.R. Boyd, H. Reemtsma, D. A. Grimm and S. Mitra, Sci. Total Environ., 311, 135 (2003).

21. M.C. Dodd and C. Huang, Environ. Sci. Technol., 38, 5607 (2004).

22. Q.D. Qiao, Q. Li and D.Y. Yu, J. Fushun Petroleum Inst., 22, 1(2002).

23. R. Kuhn, M. Pattard, K. Pernak and A. Winter, Water Res., 23, 495 (1989).

24. K.-P. Henschel, A. Wenzel, M. Diedrich and A. Fliedner, Regul. Toxicol. Pharm., 25, 220 (1997).

25. B.E. Logan, Microbial Fuel Cells, WileyInterscience, American (2008).

26. M. Huang, J.Q. Wang and C.Z. Zhu, J. Hefei Univ. Technol. (Nat. Sci.), 31, 1574 (2008). 